\section{Reseña de Imaginarios del cine chileno $y$ latinoamericano}

\author{
Ángel Miquel \\ miquel@uaem.mx
}

Universidad Autónoma del Estado de Morelos, México

https://doi.org/10.32870/ elojoquepiensa.v0i18.314

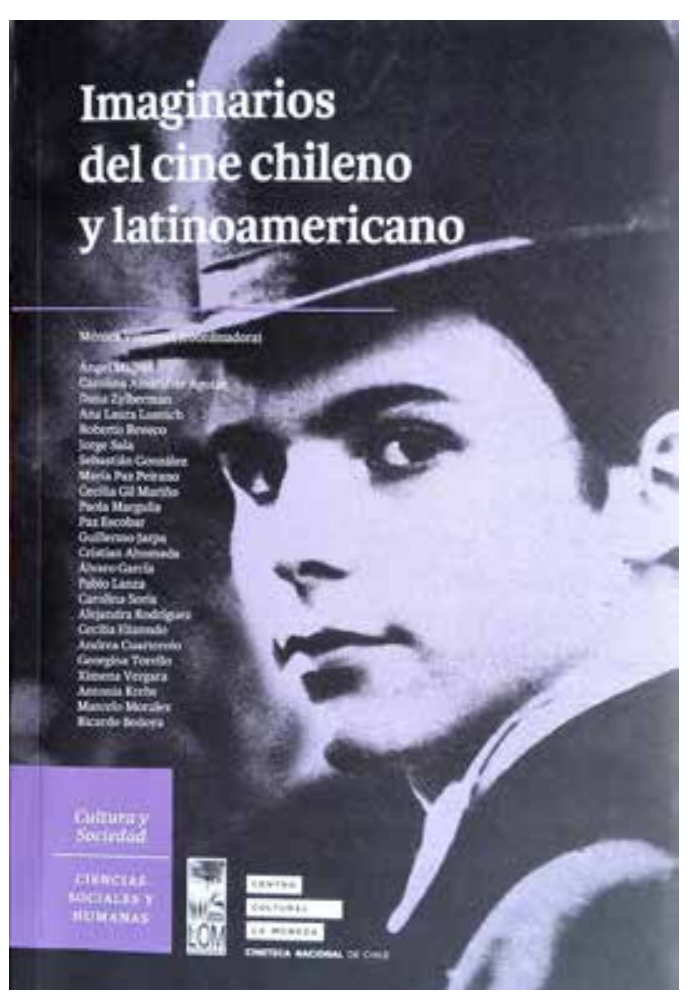

Este volumen es el sexto preparado por Mónica Villarroel para recoger las principales aportaciones de los encuentros organizados con admirable constancia por la Cineteca Nacional chilena desde 2011. En conjunto, se han compilado en estos libros alrededor de 130 trabajos de otros tantos investigadores provenientes de Argentina, Bolivia, Brasil, Colombia, España, Estados Unidos, Francia, México, Perú y Uruguay. Los textos reunidos expresan una pluralidad de intereses, metodologías y puntos de vista que da buena cuenta de la vitalidad de las comunidades de estudio de estos países. Además del abordaje de películas específicas basado en tradiciones de análisis formal o contextual, pueden destacarse en ellos temas generales como los siguientes: identidad, memoria, legislación, educación, crítica, censura, políticas públicas, preservación; producción estatal, independiente y amateur en formatos no profesionales; estudios, circuitos de distribución, cines... Es interesante que en esos libros se preste prácticamente la misma atención al cine documental que al de ficción. Y, en otro sentido, que se refieran a todos los periodos históricos, desde los orígenes a la actualidad, aunque los más tratados sean, comprensiblemente, los de las "épocas de oro" mexicana y argentina, y los de las dictaduras.

Por otra parte, estos libros también son testimonio de la creciente legitimación de los estudios sobre cine en nuestras comunidades académicas, ya que, junto a los textos de investigadores de larga trayectoria, recogen aportaciones de jóvenes que realizan o realizaron recientemente maestrías o doctorados, o que ya trabajan en instituciones universitarias, cinetecas o centros de investigación. Es muy estimulante percibir en estas obras el interés que las industrias, protagonistas y películas de nuestros países despiertan en las nuevas generaciones.

En particular, Imaginarios del cine chileno y latinoamericano incorpora veinte ensayos presentados originalmente como ponencias en el VI Encuentro Internacional de Investigación sobre Cine Chileno y Latinoamericano celebrado en Santiago en 2017. No se trata, sin embargo, de la memoria de ese evento, sino de un volumen que ofrece textos seleccionados a través de dictámenes académicos, organizados luego por la coordinadora del libro en cuatro secciones temáticas además de un dossier dedicado al cine silente. Articula al conjunto un concepto, el de imaginario, derivado de las obras de Edgar Morin y Gilbert Durand, según el cual las imágenes cinematográficas constituyen un repositorio donde -y aquí cito la presentación del libro- "se manifiestan deseos, sueños y mitos" de quienes las realizan para expresar aspectos complejos de la realidad, en este caso la de los países latinoamericanos.

Para hacer un breve resumen de la obra comenzaré por el cine silente porque esto permitirá hacer un recorrido cronológico de los contenidos. En tres de los ensayos 
que abordan este periodo, de Andrea Cuarterolo, Georgina Torello y Ricardo Bedoya, se analizan facetas interesantísimas de la producción silente: la de películas quirúrgicas en Argentina, la hecha por aficionados con fines de entretenimiento privado en Uruguay y la realizada por un cineasta chileno, Alberto Santana, quien filmó cinco películas mudas y la primera sonora en Perú. Por otro lado, el grupo de investigadores conformado por Ximena Vergara, Antonia Krebs, Marcelo Morales y Mónica Villarroel presenta sus avances en la sistematización de la filmografía chilena documental entre 1897 y 1933, realizados tras un exhaustivo rastreo hemerográfico. Además del conocimiento puntual que aportan, estos acercamientos sugieren nuevas vías de investigación sobre uno de los periodos de más difícil estudio de las cinematografías latinoamericanas, por haberse perdido la gran mayoría de sus producciones.

Otros cinco textos se enfocan en los cines industriales de las dos primeras décadas del sonoro. En esos trabajos, Ángel Miquel analiza el impacto del cine mexicano en Santiago de Chile en los primeros años 30; Dana Zylberman la trayectoria de la estrella Libertad Lamarque trasladada a México; Cecilia Gil Mariño el trabajo del realizador Carlos Hugo Christensen en Brasil, y Pablo Lanza la trilogía policiaca realizada a principios de los 50 por el director Luis Napoleón Duclout, mejor conocido como Don Napy. Estas calas en los cines clásicos tienen como puntos comunes, como ocurría también con la aproximación a la obra de Santana, resaltar la itinerancia de directores, intérpretes e incluso distribuidores, así como la búsqueda (o el encuentro) de géneros fílmicos populares.

Roberto Reveco, en un ensayo de corte teórico y ejemplificado con textos aparecidos en la publicación chilena Ecran en los años 50, eleva una crítica contra el esfuerzo, que el autor considera reduccionista, de algunos sectores intelectuales por codificar y comprender el surgimiento de las películas que vulneraron las convenciones narrativas del cine clásico. La mención de este ensayo sirve aquí a manera de bisagra para transitar hacia cinco textos en los que se analizan películas producidas entre 1972 y 1992. Carolina Amaral de Aguiar hace una interesante recreación de cómo una serie de documentales oficialistas producidos en México sobre la Unidad Popular chilena fueron reutilizados por el cineasta Carlos Ortiz Tejeda para hacer una obra personal ganadora de un premio en un festival de Alemania. Ana Laura Lusnich muestra cómo ciertos sectores de la sociedad civil (cineastas, periodistas y público) pudieron evadir, con retóricas ingeniosas y otras estrategias, las rígidas imposiciones censoras de la dictadura militar argentina. En un sentido opuesto, Jorge Sala da cuenta de cómo otros sectores de esa misma sociedad (en este caso el clero y otros periodistas), lograron investirse, ya en el periodo de la democracia, como un órgano censor de facto que impidió durante largos años la exhibición de una cinta. En un 
acercamiento complementario, Paola Margulis analiza dos documentales en los que se expresa un cierto desencanto colectivo al venirse abajo expectativas políticas y económicas creadas por la transición argentina. Guillermo Jarpa y Cristian Ahumada descubren finalmente, en cuatro largometrajes de ficción realizados en Chile durante la dictadura, elementos críticos ocultos, como ocurría en la cinta argentina analizada por Lusnich, aunque en este caso aunados curiosamente a una aspiración de éxito comercial. Se advierte en este grupo de ensayos la necesidad de continuar con la reflexión sobre las múltiples formas de representación de una de las etapas más complejas y problemáticas de la historia latinoamericana reciente.

Siete ensayos se enfocan en asuntos contemporáneos, al traer a escena películas o procesos de los años más recientes. En cinco de estos casos la aproximación se realiza, de nuevo, a través del análisis de obras fílmicas particulares. Paz Escobar hace un análisis de las que han representado la Patagonia, encontrando en ellas como elemento común un discurso turístico que exalta la naturaleza exótica y borra otras facetas de la región, como su pluralidad, historicidad y problemática social. Cecilia Elizondo aborda la representación de un mismo espacio, el Colegio Nacional Buenos Aires, en dos películas de distintos periodos que, a su vez, son adaptaciones de obras escritas. Esto le permite una sugestiva indagación intermedial similar a la que realiza Alejandra F. Rodríguez a partir de dos obras argentinas que incluyen pinturas clásicas como elementos destacados de su narración visual. Carolina Soria estudia por su parte una serie televisiva argentina lanzada en 2012, intentando identificar marcas autorales definitorias de la poética de la realizadora Albertina Carri, mientras Álvaro García se acerca a tres documentales que retrataron el movimiento estudiantil chileno de 2011, descubriendo en ellos elementos comunes tanto a su apelación política a sectores sociales que rebasan al estudiantil como a su distanciamiento radical hacia el Estado. Los últimos dos textos incluidos en el libro, de Sebastián González y María Paz Peirano, se aproximan a los Festivales en Cine en Chile en los últimos veinte años. Entre ambos refieren el surgimiento y la diseminación de estos eventos, sugiriendo que resultan en la actualidad fundamentales para difundir las películas producidas en el país, para educar a profesionales y artistas, así como para promover la creación y sensibilización de nuevas audiencias. En este último conjunto vemos representados los intereses teóricos contemporáneos de relacionar al cine con otros medios y de estudiar sus esferas aledañas inmediatas, como las de su promoción local, nacional o internacional.

Imaginarios del cine chileno y latinoamericano es, de esta forma, un libro de muy estimulante lectura. Publicado con esmero, se suma a los cinco volúmenes previos coordinados por Mónica Villarroel: Enfoques al cine chileno en dos siglos (2013), Travesías por el cine 
chileno y latinoamericano (2014), Nuevas travesías por el cine chileno y latinoamericano (2015), Memorias y representaciones en el cine chileno y latinoamericano (2016) y De Ruiz a la utopia contemporánea en el cine chileno y latinoamericano (2017). Con este encomiable esfuerzo, la Cineteca Nacional de Chile y Editorial Lom se colocan, indudablemente, a la vanguardia de las publicaciones académicas sobre las cinematografías de nuestros países.

\section{Bibliografía}

Villarroel, M. (Coord.). Imaginarios del cine chileno y latinoamericano. Santiago, Chile: Centro Cultural la Moneda, Cineteca Nacional de Chile y Lom Ediciones.

Ángel Miquel (México) es Profesor de la Facultad de Artes de la Universidad Autónoma del Estado de Morelos y egresado del doctorado en Historia del Arte de la UNAM. Se especializa en el estudio del cine mexicano y su cultura. También ha incursionado en la escritura de ficción. Entre sus libros recientes se encuentran el ensayo Crónica de un encuentro: el cine mexicano en España, 1933-1948 (UNAM, 2016) y la novela Tolvanera (Ediciones Sin Nombre y Secretaría de Cultura, 2017). 